\title{
The Role of user Involvement in the Success of Project Scope Management:
}

\author{
Jordanian Government IT Departments
}

\author{
Maha Alkhaffaf ${ }^{1}$ \\ Management Information System Department, Jordan \\ The World Islamic Sciences and Education University \\ Amman-Jordan
}

\begin{abstract}
Greater emphasis is now being placed on User Involvement as a factor imperative to Success in Project Scope Management. Although Project Scope Management Processes have a tendency to centre on various factors pertaining to the collecting criteria, defining scope and verifying scope, controlling scope is viewed as being fundamental to the management process as a whole. Furthermore, Success in Project Scope Management in the modern-day competitive business setting is recognised as resting on efficient and effective processes applied across Project Scope Management. One essential factor in achieving success in this arena is that of User Involvement. In this regard, the point is presented that Project Scope Management and User Involvement may be implemented in such a way so as to enhance Successful Project Scope Management. A questionnaire-centred survey approach utilizing Project Scope Management Processes and User Involvement to Successful Project Scope Management, encompassing management- and strategy-level employees, totalling 295, was applied in order to establish the link, both indirect and direct, between particular elements influencing four different IT departments at the governmental level. The data gathered underwent analysis through the use of SPLS (Smart Partial Least Square). This work provides a valuable contribution for professionals in the field, both in terms of researchers and practitioners, and further highlights the different ways in which project managers can arrange and modify Project Scope Management Processes in pursuit of their efforts to enhance the mediation of Successful Project Scope Management through User Involvement.
\end{abstract}

Keywords-Gathering requirements; defining scope; verifying scope; controlling scope; and user involvement

\section{INTRODUCTION}

A large number of businesses recognise the fact that a significant degree of their effectiveness depends on how Project Scope Management is applied and managed. Accordingly, there is a need for organisations to establish the Project Scope Management Processes and subsequently outline and identify the role adopted by User Involvement when it comes to attaining success in Project Scope Management. Furthermore, it is recognised that there are various difficulties in Project Scope Management [1] [2] [3], with the business viewed as fluid and changeable. The field involves a great variation of users in different projects in mind of achieving varying goals across differing settings. With this taken into account, as highlighted by [4], project management may be positioned in such a way so as to facilitate businesses in strategically structuring themselves to attain their business objectives and subsequently enhance their competitiveness across their industry.

Furthermore, a number of different researchers have presented the recommendation that Project Management (PM) seeks to redirect away from more conventional approaches to more generalised management principles [19], specifically when there are complex environments as the setting for projects [5]. Moreover, in the study of Ajelabi \& Tang [2010], it was recognised that, with the passing of time and the greater wealth of experience and literature, [7] PM theory has provided a valuable instrument when it comes to change implementation across businesses. In addition, the work of Kwak \& Anbari [2009] highlights the need for PM theory practitioners to encourage the adoption of PM theory as an academic discipline. Owing to the widely acknowledged value of the field, Project Scope Management has become recognised as an imperative consideration across different sectors in Jordan; therefore, in-depth and wide-ranging expertise in this area has become recognised as necessary.

Project Scope management processes across businesses and new project managers [9] undergoing training lead the overall process of the project, and are viewed as fundamental organisational change in line with project implementation success. In addition, a number of different project organisations, such as Oracle, SAP and Microsoft, amongst others, place much emphasis on the best, most innovative practices, such as those carried out in significant businesses, [10] i.e. IT departments in governmental institutions, which have in place environmental professionals employed in order to garner insight into the required experiences [11].

One problem with this particular solution is that Project Scope Management does not always encompass User Involvement; specifically, they provide management support, as well as support to the project user, with User Involvement not always incorporated within the team. In such instances, there is a need for the project management to be clear on the issues pertaining to User Involvement so as to ensure the necessary support is provided. Project Scope Management processes need to be assigned in such a way so as to include the most important and valid data, with this updated and related to the greatest possible degree. It is not always feasible for this to be achieved owing to the fact that varying degrees of precision are required in different areas. In order to ensure 
the data is kept informed and relevant, it is important that there are updates and feedback whenever necessary [6]. The issue is to determine the way in which Successful Project Scope Management can be achieved, whilst also ensuring a significant usage level and understanding. The most optimal situation is that all of the necessary data exists across the Scope Management processes, and that user information is kept updated and valid, with continuous development through User Involvement across all stages. When it comes to dealing with this particular issue, the aim was suggesting a conceptual framework relating to the Project Scope Management Processes, bringing together Successful Project Scope Management and User Involvement. Accordingly, this particular work completes an analysis on the link between Project Scope Management Processes, User Involvement, and the effects of such in line with Project Scope Management success.

This study is broken down into six key sections in an effort to describe Project Scope Management. First and foremost, there is an introduction into the most pertinent of considerations and the value acknowledged in Project Scope Management Processes and User Involvement. Secondly, a review of the relevant literature relating to Project Scope Management Processes is presented, along with the value of User Involvement in line with Project Scope Management success. Third, there is the presentation of the hypotheses and conceptual framework. Following is an explanation of the research methodology, with the fifth section providing the data analysis findings, whilst the sixth section draws its conclusions.

\section{LITRATUR REVIEW}

\section{A. Project Scope Management Processes}

The country of Jordan is recognised as being in its developmental stages, with decentralisation presenting a number of challenges in administration and local governments, in combination with work processes undergoing globalisation and there being much significant development in ICT trends - all of which are recognised as having a key and significant effect on the organisational capacity of Jordan, Furthermore, businesses are called upon to implement plans and present innovative ideas[12]. There is much emphasis being placed on change, which is encouraging firms to establish their systems and projects [13], [14]. Accordingly, a significant wealth of knowledge in the literature in the area of Project Management, IT projects and Project Scope Management is now available [15]; [16]; [17]; [18]. Furthermore, various researchers have completed analyses on the effect of Project Management on project success. As an example, the study of Nikumbh \& Pimplikar [2014] describes PM as being a skill identifiable as a human and material resource centred on leading and organising throughout a project's lifecycle, notably through modern management method development in such a way so as to attain the outlined aims of scope, cost, participation satisfaction, quality and time.

Furthermore, the Project Management Institute (PMI) recognises the key skills needing to be offered by an efficient and valuable project manager [20]. First and foremost, the key competencies are recognised as scope management, with scholars Sánchez \& Schneider [2014] describing international project management organisations as having created their own project management guidelines upon knowledge areas [21], with the inclusion of scope management. Moreover, it has been stated by Marinho et al. [2014] that the majority of projects have come to experience restrictions in regards costs, scope and time, in addition to particular principles relating to quality [22].

Nonetheless, in an effort to teach management and businesses the key role of User Involvement in line with Successful Project Scope Management, there is a need to define the success of Project Scope through completing an evaluation on the approval of the user. As such, one fundamental aspect of Successful Project Scope Management is that of User Involvement. Moreover, as highlighted by PMI [2013] Project Scope Management Processes may be broken down into four different process groups, namely Collecting Requirements, Defining Scope, Verifying Scope, and Controlling Scope.

\section{B. The Value Recognised in user Involvement in Line with Project Scope Management Success}

During more recent times, User Involvement has become acknowledged as a resource encouraging and facilitating success in Project Scope Management across a number of business organisations. Various authors, including [10] Travaglini et al. [2014], recognise that stakeholder executive is one of the most important project success aspects owing to the fact that success in projects is significantly dependent on stakeholder satisfaction. Furthermore, project management experts are highlighted by [23] Seresht et al. [2014] as continuing to show a lack of consensus in relation to how project success may be defined and measured. The work of [2] Morris [2010] further emphasises that PM is becoming more and more widely used and in such a way so as to include the user across all arenas. It is important to recognise that future projects need to place greater emphasis on user-specific deliverables as quickly as possible.

Nonetheless, in the view of [7] Mian et al. [2010], a project is recognised as involving various individuals all working in unison on a common task, sharing the tasks, resources and responsibilities so as to achieve success. It has been stated by [3] Too \& Weaver [2014] that actual PM encompasses a number of different objectives, in addition to an agreement between the project manager and user on how such objectives will be fulfilled. Furthermore, the point has been made by [24] Nenni et al. [2014] that a number of different professionals and academics in the field have examined the way in which processes and approaches can be improved in an effort to achieve efficiency improvements in attaining the project goals of a firm. Moreover, it is noted in the work of [15] Al Freidi [2014] that professional project management tools may be utilised so as to document and monitor the progress of a project, [8] which subsequently can lead to success. There is strict adherence to project planning and monitoring, as well as communication between the user and project manager, all as part of the management infrastructure applied throughout the lifecycle of the project. 
A research by [25] Mir \& Pinnington [2014] details that the framework presents a number of different factors underpinning project success, with the inclusion of business success, customers, efficiency, future preparation, and the influence of achieving a competitive edge.

In addition, the study carried out by [26] Purna [2012] highlighted communication management between the various parties in a project as being well-detailed in the literature, predominantly owing to the emphasis placed on this part of PM and its recognised influence in project success. As such, User Involvement across all of the Project Scope Management processes results in a greater degree of success in Project Scope Management. Furthermore, preliminary scope statements are identified by [27] Silvius \& Schipper [2014] as highlighting the needs and expectations of stakeholders through user involvement across all a project's aspects.

\section{RESEARCH MODEL AND HYPOTHESES DEVELOPMENT}

In the recent past, Project Scope Management and User Involvement process have been identified as fundamental when striving to achieve Project Scope Management success. Accordingly, the research available in the field of Project Scope Management Processes and User Involvement in line with Project Scope Management success is examined in this work. In line with this, the researcher presents a framework with the aim of emphasising the casual links between the various Project Scope Management Processes (Collecting requirements, Defining scope, Verifying scope, controlling scope [20] and User Involvement with the aim of achieving improvement across Project Scope Management success.

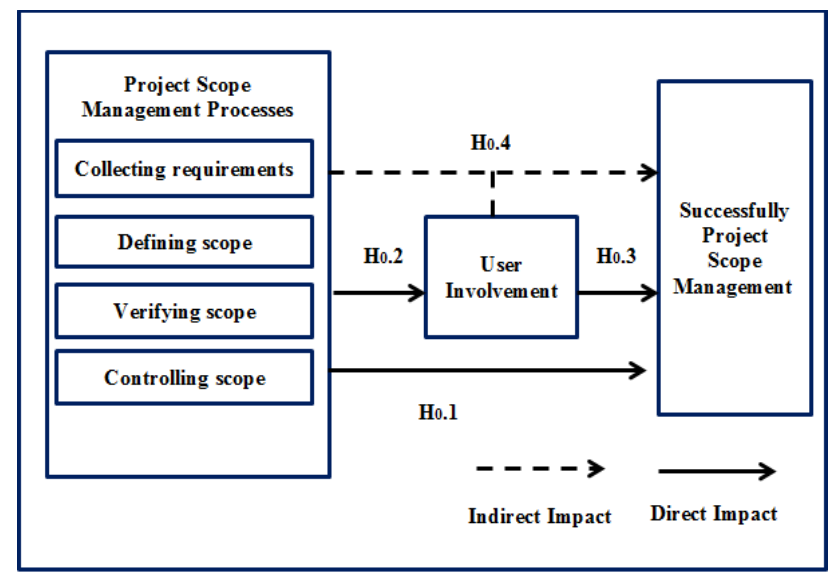

Fig. 1. Proposed Model.

In line with that stated above, Project Scope Management processes [20] implementation is recognised as appropriate in this work for various reasons: firstly, the technique of Project Scope Management facilitates project managers and supervisors in assigning the most appropriate volume of work to achieve successful project completion; secondly, the majority of project methodologies warrant that the scope of a project is outlined in the first instance; and lastly, the PMBOK Guide is concerned with providing a further breakdown of project management knowledge that, as a whole, is acknowledged as being good practice for Project Scope Management processes [28]. Throughout this particular work,
User Involvement adopts a mediatory role in the link between Project Scope Management Processes and achieving success in Project Scope Management. The diagram below "Fig. 1" provides an overview of this work's model.

The above "fig 1" encompasses a total of 6 different factors, 4 of which are linked with Project Scope Management Processes whilst the remainder are linked with User Involvement and Successful Project Scope Management. The suggested model is recognised as comprising a number of different processes, as detailed as following:

\section{A. Collecting Requirements:}

This comprises explaining and detailing the functionality and overall structure of the products generated across the preliminary organisation of the project.

\section{B. Defining Scope:}

This phase relates to the review of all project charter elements, with the inclusion of the preparation of the necessary documents and the assets of the organisational processes applied in order to create a scope statement.

\section{Verifying Scope:}

This approach encompasses the formalisation of approval regarding the project deliverables.

\section{Controlling Scope:}

Relating to project scope changes, and the control of such, throughout the project's lifecycle.

\section{E. User Involvement:}

Centred on the process of assigning all users recognised as being of influence to the project team, with assignment to the project team, whilst also outlining their responsibility in Collecting requirements, Defining scope and Verifying scope.

\section{F. Successful Project Scope Management:}

Considers Project Scope Management, with the inclusion of those processes validating the project whilst addressing all of the components fundamental when seeking to achieve success in Project Scope Management.

At the first stage, the direct effects acknowledged as relevant in Project Scope Management Processes and Successful Project Scope Management will be measured in H.1, which includes a total of four different sub-hypotheses, detailed as follows:

H.1.1: Collecting requirements is recognised as having a significant effect on Successful Project Scope Management at $(\alpha \leq 0.05)$.

H.1.2: Defining scope is recognised as having a significant effect on Successful Project Scope Management at ( $\alpha \leq 0.05)$.

H.1.3: Verifying scope is recognised as having a significant effect on Successful Project Scope Management at $(\alpha \leq 0.05)$.

H.1.4: Controlling scope is recognised as having a significant effect on Successful Project Scope Management at $(\alpha \leq 0.05)$ 
Throughout this work, the direct effects acknowledged as relevant in regards Project Scope Management Processes and User Involvement will be measured in H.2, which includes a total of four different sub-hypotheses, detailed as follows:

H.2.1: Collecting requirements is recognised as having a significant effect on User Involvement at $(\alpha \leq 0.05)$.

H.2.2: Defining scope is recognised as having a significant effect on User Involvement at $(\alpha \leq 0.05)$ H.2.3: Verifying scope is recognised as having a significant effect on User Involvement at $(\alpha \leq 0.05)$. H.2.4: Controlling scope is recognised as having a significant effect on User Involvement at $(\alpha \leq 0.05)$. Subsequently, throughout this work, the direct link between User Involvement and Successful Project Scope Management will be measured in H.3, which includes one sub-hypotheses, detailed as follows:

H.3.1: User Involvement is recognised as having a significant direct on Successful Project Scope Management at $(\alpha \leq 0.05)$

Lastly, throughout this work, the links between Project Scope Management Processes and their effect on User Involvement and Successful Project Scope Management will be considered through the application of H.4, which includes a total of four sub-hypotheses, detailed as follows:

H.4.1: User Involvement is recognised as mediating the link of Collecting requirements and Successful Project Scope Management at a significant level $(\alpha \leq 0.05)$

H.4.2: User Involvement is recognised as mediating the link of defining the scope and Successful Project Scope Management at a significant level $(\alpha \leq 0.05)$. H.4.3: User Involvement is recognised as mediating the link of verifying scope and Successful Project Scope Management at a significant level $(\alpha \leq 0.05)$ H.4.4: User Involvement is recognised as mediating the link of controlling the scope and Successful Project Scope Management at a significant level $(\alpha \leq 0.05)$.

\section{RESEARCH METHODOLOGY}

The questionnaire detailed the individual constructs to undergo measurement throughout the quantitative analysis [29]. Data were gathered through the adoption of a survey questionnaire [30] to determine the opinions of employees at the strategic and management level. Furthermore, random sampling was carried out across four IT departments at the government level.

\section{A. Sample size}

Owing to the varying sizes of the IT departments included in this work, the research has implemented a specific distribution technique so as to ensure the accurate representation of the research population. The sample of this work encompasses the four IT departments at the government level included in this work. Table 1 provides an overview of the findings of the sample size, in line with the analysis of 295 completed questionnaires.
TABLE I. THE QUESTIONAIR COLLECTED AND COMPLETED PER GOVERNEMNT IT DEPARTMENT

\begin{tabular}{|l|l|}
\hline Sector & $\begin{array}{l}\text { Completed questionnaires } \\
\text { collected }\end{array}$ \\
\hline $\begin{array}{l}\text { First government IT department } \\
\text { Income tax corporation }\end{array}$ & 27 questionnaires \\
\hline $\begin{array}{l}\text { Second government IT department } \\
\text { Jordanian water authority }\end{array}$ & 33 questionnaires \\
\hline $\begin{array}{l}\text { Third government IT department } \\
\text { Jordanian Ministry of Water }\end{array}$ & 45 questionnaires \\
\hline $\begin{array}{l}\text { Fourth government IT department } \\
\text { Grater Amman Municipality }\end{array}$ & 190 questionnaires \\
\hline Total & 295 questionnaires \\
\hline
\end{tabular}

\section{DATA ANALYSIS AND RESULT}

\section{A. Demographic Data Results}

The majority of the staff were males, with only one-fifth $(21 \%)$ of the sample female. Furthermore, approximately onethird (36.9\%) of the staff were aged between 31 and 35 years. In regards the participants' specialisations, approximately $41.1 \%$ of the participants were involved in group project management. Furthermore, just over one-quarter (26.4\%) of the sample were in the role of System analyst, whilst a similar proportion $(24.7 \%)$ carried out roles in hardware and software. In addition, more than half (53.9\%) were seen to have at least seven years' experience. Table 2 provides an overview of the demographic data.

TABLE II. DEMOGRAPHIC DATA Results

\begin{tabular}{|c|c|c|c|}
\hline Description & Variable & Result & Percentage \\
\hline \multirow{2}{*}{ Gender } & Male & 233 & $79.0 \%$ \\
\hline & Female & 62 & $21.0 \%$ \\
\hline \multirow{4}{*}{ Age } & Less than 25 years & 41 & $13.9 \%$ \\
\hline & 25-30 years & 80 & $27.1 \%$ \\
\hline & $31-35$ years & 109 & $36.9 \%$ \\
\hline & More than 35 years & 65 & $22.0 \%$ \\
\hline \multirow{4}{*}{$\begin{array}{l}\text { Area of } \\
\text { Specialization }\end{array}$} & $\begin{array}{l}\text { Hardware and } \\
\text { software }\end{array}$ & 73 & $24.7 \%$ \\
\hline & System analyst & 78 & $26.4 \%$ \\
\hline & Project management & 122 & $41.4 \%$ \\
\hline & Other & 22 & $7.5 \%$ \\
\hline \multirow{4}{*}{ Experience } & Less than 1 year & 4 & $1.4 \%$ \\
\hline & $2-7$ years & 83 & $28.1 \%$ \\
\hline & $7-13$ years & 159 & $53.9 \%$ \\
\hline & More than 13 years & 49 & $16.6 \%$ \\
\hline
\end{tabular}




\section{B. Validity and Reliability Result}

Throughout this work, Smart Partial Least Square (PLS) was applied with the aim of measuring all hypotheses; there was the completion of data analysis through the application of two different phases [31], [32]: the first analysed the overall validity and reliability, whilst the second completed hypotheses testing.

\section{- Path Loadings}

Throughout this work, path loadings for all variables incorporated across the model were found to exceed $(0.50)$ through the application of PLS software, thus meaning the acceptance of all variables, as highlighted by Falk \& Miller [1992]. The figure below provides an explanation as to the path loadings (factors analysis result) for all variables included in the study model.

"Fig. 2" details six individual elements (Collecting requirements, Defining scope, Verifying scope, Controlling scope, User Involvement, and Successful Project Scope Management). Table 3 below provides an overview of the research constructs' Measure, Item and Factor Loading.

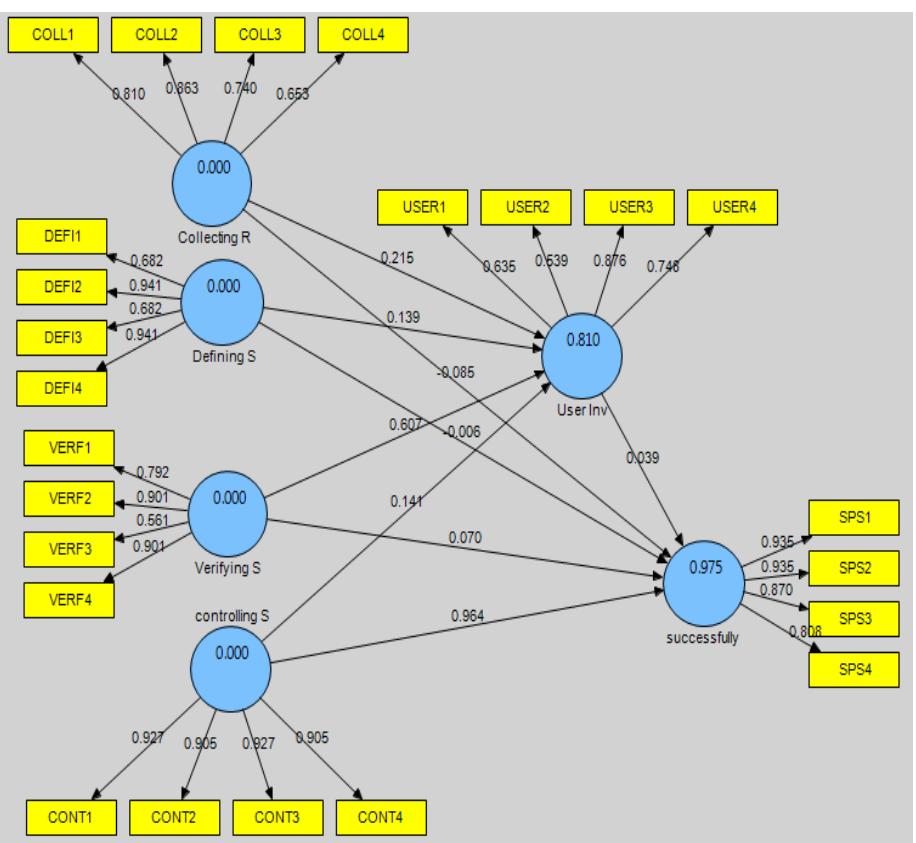

Fig. 2. Path Loading.

TABLE III. CONSTRUCT MESURMENTS

\begin{tabular}{|c|c|c|c|}
\hline Variables & Item & $\begin{array}{l}\text { Factors } \\
\text { loading }\end{array}$ & Measure \\
\hline \multirow{4}{*}{ Collecting requirements } & COLL1 & 0.81 & Collecting requirements is concerned with defining the functions. \\
\hline & COLL2 & 0.66 & Collecting requirements is concerned with detailing the features \\
\hline & COLL3 & 0.74 & Collecting requirements in the business setting require top management support \\
\hline & COLL4 & 0.65 & $\begin{array}{l}\text { The requirements management plan provides good practice in regards Collecting } \\
\text { requirements }\end{array}$ \\
\hline \multirow{4}{*}{ Defining scope } & DEFI1 & 0.68 & Preparing project scope statement input includes the project charter \\
\hline & DEFI2 & 0.94 & The assets of the organisational process are applied in defining scope \\
\hline & DEFI3 & 068 & The key objectives pertaining to Defining scope determine the project scope statement \\
\hline & DEFI4 & 0.94 & As time progresses, project scope should become apparent \\
\hline \multirow{4}{*}{ Verifying scope } & VERF1 & 0.79 & The approved project scope statement form the scope baseline \\
\hline & VERF2 & 0.90 & Scope verification includes stakeholders' acceptance of project scope completion \\
\hline & VERF3 & 0.56 & Verifying scope relies on project scope quality \\
\hline & VERF4 & 0.90 & $\begin{array}{l}\text { Project managers apply leadership skills in such a way so as to deal with and manage the } \\
\text { various obstacles experienced throughout the Verifying scope stage. }\end{array}$ \\
\hline \multirow{4}{*}{ Controlling scope } & CONT1 & 0.92 & Scope control encompasses project scope change control \\
\hline & CONT2 & 0.90 & $\begin{array}{l}\text { The objective underpinning scope control is to affect the factors underpinning scope } \\
\text { changes }\end{array}$ \\
\hline & CONT3 & 0.92 & The key outcomes associated with controlling scope include Variance reports \\
\hline & CONT4 & 0.90 & The IT department is pivotal in achieving controlling scope success \\
\hline \multirow{4}{*}{ User Involvement } & USER1 & 0.63 & User Involvement ensures the scope is kept realistic \\
\hline & USER2 & 0.53 & User Involvement results in the project selection process being valuable and good \\
\hline & USER3 & 0.78 & $\begin{array}{l}\text { User Involvement throughout the processes of Project Scope Management provides } \\
\text { guarantees in terms of flexibility when changing work requirements }\end{array}$ \\
\hline & USER4 & 0.74 & User Involvement is recognised as pivotal in line with change requests \\
\hline \multirow{4}{*}{$\begin{array}{l}\text { Successfully Project } \\
\text { Scope Management }\end{array}$} & SPS1 & 0.93 & $\begin{array}{l}\text { The success of Project scope requires performance to be measured throughout the course } \\
\text { of satisfying project scope objectives }\end{array}$ \\
\hline & SPS2 & 0.93 & $\begin{array}{l}\text { Project Scope Management success centres on providing users and sponsors with frequent } \\
\text { outcomes }\end{array}$ \\
\hline & SPS3 & 0.87 & $\begin{array}{l}\text { Project Scope Management success rests on ensuring the creation of a requirements } \\
\text { management database }\end{array}$ \\
\hline & SPS4 & 0.80 & $\begin{array}{l}\text { Changes from a systems perspective should be reviewed if they are to result in Project } \\
\text { Scope Management success }\end{array}$ \\
\hline
\end{tabular}




\section{- The Measurement Model}

Through the use of PLS software, all Cronbach Alpha (CA) and composite reliability (CR) scores were seen to be higher than the suggested value (0.65) [33], which implies that all of the constructs detailed in the model offer good reliability. A commonly practical convergent validity standard is AVE (average variance extracted), as suggested in the work of Fornell \& Larcker [1981]; this is seen to span 0.50-0.83, which falls within the scope of the cut-off value of 0.50 or higher. Table 4 below details the reliability AVE and CR for the constructs in this work, with all of them found to exceed the suggested levels.

TABLE IV. MESURMENT MODEL RESUlts

\begin{tabular}{|l|l|l|l|}
\hline Constructs & $\begin{array}{l}\text { Cronbach } \\
\text { Alpha (CA) }\end{array}$ & $\begin{array}{l}\text { Average } \\
\text { Variance } \\
\text { Extracted (AVE) }\end{array}$ & $\begin{array}{l}\text { Composite } \\
\text { Reliability (CR) }\end{array}$ \\
\hline $\begin{array}{l}\text { Collecting } \\
\text { requirements }\end{array}$ & 0.77 & 0.59 & 0.85 \\
\hline Defining scope & 0.85 & 0.67 & 0.89 \\
\hline Verifying scope & 0.80 & 0.64 & 0.87 \\
\hline controlling scope & 0.93 & 0.83 & 0.95 \\
\hline User Involvement & 0.67 & 0.50 & 0.79 \\
\hline $\begin{array}{l}\text { Successful Project } \\
\text { Scope Management }\end{array}$ & 0.90 & 0.78 & 0.93 \\
\hline
\end{tabular}

- $\mathrm{R}$ (Square) Test

The value of $\mathrm{R}$ (Square) coefficient is applied for the central approach to the structural Model's measurement for the suggested model, as highlighted in Table 5.

TABLE V. R (SQUARE) VALUE

\begin{tabular}{|l|l|}
\hline Relation & $\begin{array}{l}\mathrm{R} \\
\text { (Square) }\end{array}$ \\
\hline $\begin{array}{l}\text { The effects of Project Scope Management processes in } \\
\text { line with Project Scope Management success without } \\
\text { User Involvement mediation }\end{array}$ & 0.81 \\
\hline $\begin{array}{l}\text { The effect of the processes of Project Scope Management } \\
\text { on Project Scope Management success with User } \\
\text { Involvement mediation }\end{array}$ & 0.97 \\
\hline
\end{tabular}

The effects of Project Scope Management processes in line with Project Scope Management success without User Involvement mediation $\quad 0.81$

The effect of the processes of Project Scope Management on Project Scope Management success with User Involvement mediation $\quad 0.97$

Table 5 details that the R-squares for the variables (i.e. Project Scope Management success) without mediation achieves a value of 0.81 , which is recognised as exceeding $25 \%$, in line with the suggestion of Hair ,Black, Babin, Anderson and Tatham. [2006], which measures the accepted prediction level across the empirical paper [34]. In contrast, the variable's R (Square) value (i.e. Project Scope Management success) was mediated by User Involvement, with a value of 0.97 achieved, which is seen to exceed $25 \%$; there was an increase in the percentage of Successful Project Scope Management R (Square) by $16 \%$ when there was the inclusion of User Involvement as the mediation variable in the link between Project Scope Management processes and Project Scope Management success.

\section{- Latent Variable Correlations Test}

There was the application of the Latent Variable Correlations Test in order to determine measurement construct discriminant validity (Collecting requirements, Defining scope, Verifying scope, Controlling scope, User Involvement, and Successful Project Scope Management). Table 6 provided below highlights the discriminant validity across this work.

\section{TABLE VI. DISCRIMINANT VALIDITY}

\begin{tabular}{|l|l|l|l|l|l|l|}
\hline Construct & $\begin{array}{l}\text { Collect } \\
\text { ing } \\
\text { require } \\
\text { ments }\end{array}$ & $\begin{array}{l}\text { Defi } \\
\text { ning } \\
\text { scop } \\
\text { e }\end{array}$ & $\begin{array}{l}\text { Verifyi } \\
\text { ng } \\
\text { scope }\end{array}$ & $\begin{array}{l}\text { control } \\
\text { ling } \\
\text { scope }\end{array}$ & $\begin{array}{l}\text { User } \\
\text { Involv } \\
\text { ement }\end{array}$ & $\begin{array}{l}\text { Successf } \\
\text { ul } \\
\text { Project } \\
\text { Scope } \\
\text { Manage } \\
\text { ment }\end{array}$ \\
\hline $\begin{array}{l}\text { Collecting } \\
\text { requirements }\end{array}$ & 1.00 & & & & & \\
\hline $\begin{array}{l}\text { Defining } \\
\text { scope }\end{array}$ & 0.42 & 1.00 & & & & \\
\hline $\begin{array}{l}\text { Verifying } \\
\text { scope }\end{array}$ & 0.76 & 0.55 & 1.00 & & & \\
\hline $\begin{array}{l}\text { controlling } \\
\text { scope }\end{array}$ & 0.81 & 0.52 & 0.87 & 1.00 & & \\
\hline $\begin{array}{l}\text { User } \\
\text { Involvement }\end{array}$ & -0.01 & 0.03 & 0.24 & 0.16 & 1.00 & \\
\hline $\begin{array}{l}\text { Successful } \\
\text { Project Scope } \\
\text { Management }\end{array}$ & -0.01 & 0.04 & 0.26 & 0.19 & 0.98 & 1.00 \\
\hline
\end{tabular}

In line with the information detailed in Table 6, discriminant validity was validated across the work, considering that the square root of the AVE achieved from all of the constructs was found to be greater than all other crosscorrelations with other constructs.

\section{Test Hypotheses}

The hypotheses in the model underwent measurement through the completion of T-tests through the application of Bootstrapping in smart PLS to determine the $T$ value. To begin with, the $\mathrm{T}$ value for Project Scope Management processes was measured by on Successful Project Scope Management without User Involvement as a mediatory factor. The figure below"Fig 3" provides an overview of this Bootstrapping ( $\mathrm{T}$ value).

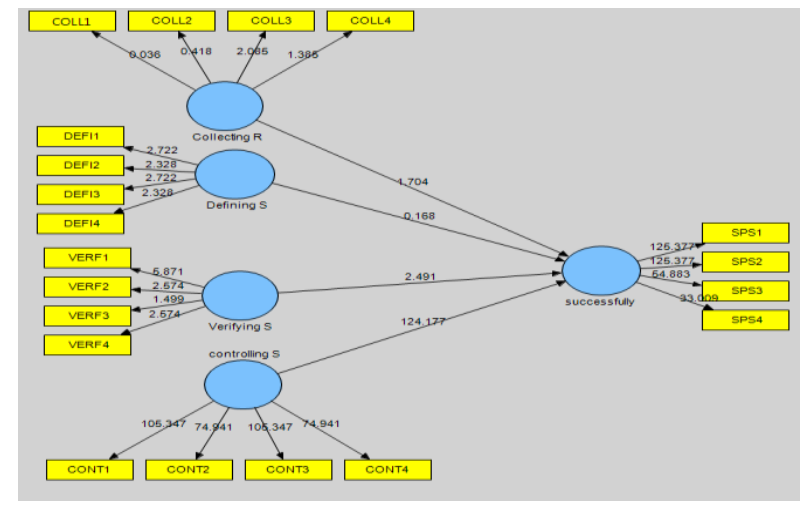

Fig. 3. Bootstrapping (T value) for Project Scope Management processes on Successful Project Scope Management without mediation of User Involvement. 
In line with the above "Fig. 3", the $\mathrm{T}$ value was determined by the authors through the application of Smart Partial Least Square (PLS) in order to test the hypotheses associated with Project Scope Management processes (Collecting requirements, Defining scope, Verifying scope, controlling scope) on Project Scope Management success without User Involvement applied as a mediatory factor. Table 7 provides the results.

TABLE VII. Test of Project SCOPE MANAGEMENT Process AND SUCCESSFUL PROJECT SCOPE

\begin{tabular}{|l|l|l|}
\hline Relation (direct effect) & $\begin{array}{l}\text { T } \\
\text { value }\end{array}$ & $\begin{array}{l}\text { Beta } \\
\text { value }\end{array}$ \\
\hline $\begin{array}{l}\text { Collecting requirements and Successful Project } \\
\text { Scope Management }\end{array}$ & 1.70 & -0.07 \\
\hline $\begin{array}{l}\text { Defining scope and Successful Project Scope } \\
\text { Management }\end{array}$ & 0.16 & 0.00 \\
\hline $\begin{array}{l}\text { Verifying scope and Successful Project Scope } \\
\text { Management }\end{array}$ & 2.49 & 0.09 \\
\hline $\begin{array}{l}\text { Controlling scope and Successful Project Scope } \\
\text { Management }\end{array}$ & 124.17 & 0.96 \\
\hline
\end{tabular}

The $\mathrm{T}$ value, in table 7 which is recognised between Collecting requirements and Successful Project Scope Management, was identified as 1.70. This is seen to be significant at the 0.05 level. Further, the Beta value is identified as -0.07 . Notably, this value provides the explanation that one degree of change in Collecting Requirements will cause -0.07 degree change in Successful Project Scope Management. As such, these findings mean H1.1 can be accepted.

The $\mathrm{T}$ value, which is between the Defining scope and Successful Project Scope Management, is determined at 0.16. This is therefore not significant at the 0.05 level. Furthermore, the Beta is recognised as 0.00 , which explains that modification to one degree of Related to the Defining Scope will induce change of 0.00 in Successful Project Scope Management. As such, these findings do not support the acceptance of H.1.2.

The $\mathrm{T}$ value, which is recognised as between the Verifying Scope and Successful Project Scope Management, was identified as 2.49. This is seen to be significant at 0.05 level. Further, the Beta value is identified as 0.09, which explains that change to one degree of Verifying Scope will induce change of 0.09 in Successful Project Scope Management. As such, these findings support the acceptance of H.1.3.

The $\mathrm{T}$ value, which is recognised between the Controlling scope and Successful Project Scope Management, was identified as 124.17. This is seen to be significant at the 0.05 level. Further, the Beta value is identified as 0.96, which explains that change in one degree of controlling scope will induce change of 0.96 in Successful Project Scope Management. As such, these findings support the acceptance of H.1.4.

In addition, the $\mathrm{T}$ value for Project Scope Management processes on Successful Project Scope Management was determined with the inclusion of User Involvement as a mediating factor. The $\mathrm{T}$ value for the study model can be seen detailed in the following figure.

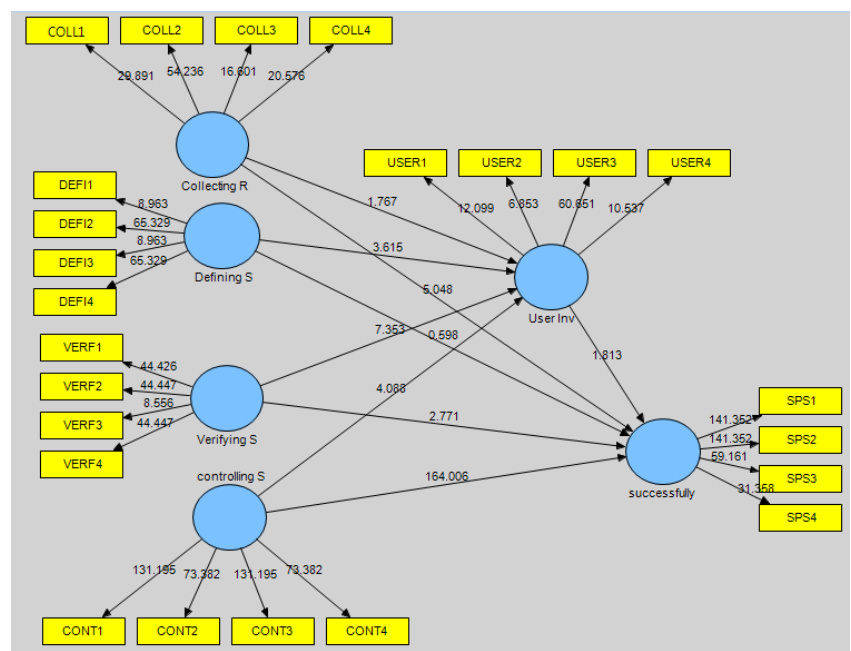

Fig. 4. Bootstrapping (T value) for Project Scope Management processes on Successful Project Scope Management with mediation of User Involvement.

In line with "Fig. 4", the $\mathrm{T}$ value has been

Established through the application of the Smart

Partial Least Square (PLS) in mind of testing all hypotheses associated with Project Scope Management processes (Collecting requirements, defining scope, verifying scope, controlling scope) and User Involvement. The results can be seen summarised in the following table 8 .

TABLE VIII. TeSt Results For Project Scope Management Process AND USER INVOLVEMENT

\begin{tabular}{|l|l|l|}
\hline Relation (direct effect) & $\begin{array}{l}\text { T } \\
\text { value }\end{array}$ & $\begin{array}{l}\text { Beta } \\
\text { value }\end{array}$ \\
\hline Collecting requirements and User Involvement & 1.89 & 0.21 \\
\hline Defining scope and User Involvement & 3.73 & 0.13 \\
\hline Verifying scope and User Involvement & 7.95 & 0.60 \\
\hline Controlling scope User Involvement & 4.54 & 0.14 \\
\hline
\end{tabular}

Table 8 provide the $\mathrm{T}$ value, which is identified between the Collecting requirements and User Involvement, is recognised as being 1.89. Accordingly, it is recognised as significant at the 0.05 level. Further, the Beta value is recognised as 0.21 , which explains that change to one degree of collecting requirements will cause change of 0.21 in User Involvement. As such, these findings facilitate the acceptance of H.2.1.

The $\mathrm{T}$ value, which is identified between the Defining scope and User Involvement, is recognised as 3.73. Accordingly, it is significant at the 0.05 level. Further, the Beta value is found to be 0.13 , which explains that change to one degree of Defining scope will cause change equal to 0.13 in User Involvement. These findings facilitate the acceptance of H.2.2.

The $\mathrm{T}$ value, which is recognised between the Verifying scope and User Involvement, is identified as 7.95. Accordingly, this is viewed as significant at the 0.05 level. In addition, the Beta value is determined to be 0.60 , which Explains that a change to one degree of Verifying scope will cause change of 0.60 in User Involvement. Such findings support H.2.3 acceptance. 
The $\mathrm{T}$ value, which is recognised between the Controlling scope and User Involvement, is identified as 4.54. Accordingly, it is significant at the 0.05 level. Further, the Beta value is recognised as 0.14 , which explains that change to one degree of controlling scope will induce change amounting to 0.14 in User Involvement. Such findings support H.2.4 acceptance.

In addition, as can be seen from Figure 4, the $\mathrm{T}$ value test is applied in the Smart Partial Least Square (PLS) with the aim of analysing the hypotheses linked to User Involvement and project success. Table 9 below provides an overview of the results.

TABLE IX. TEST RESULTS FOR USER INVOLVEMENT AND SUCCESSFUL PROJECT SCOPE MANAGEMENT

\begin{tabular}{|l|l|l|}
\hline Relation (direct effect) & $\begin{array}{l}\text { T } \\
\text { value }\end{array}$ & $\begin{array}{l}\text { Beta } \\
\text { Value }\end{array}$ \\
\hline $\begin{array}{l}\text { User Involvement and Successful Project Scope } \\
\text { Management }\end{array}$ & 1.80 & 0.03 \\
\hline
\end{tabular}

The $T$ value, which is recognised between User Involvement and Successful Project Scope Management, is identified as 1.80. Accordingly, it is seen to be significant at the 0.05 level. Further, the Beta value is determined to be 0.03 , as it is clear in table 9 , which explains that change to one degree of User Involvement will induce change of 0.03 in Successful Project Scope Management. These findings provide support for $\mathrm{H} 0.3$ acceptance.

TABLE X. TEST RESUltS FOR COLLECTING REQUIREMENTS AND SuCCESSFUl PROJECT SCOPE MANAGEMENT MEDIATING By USER INVOLVEMENT

\begin{tabular}{|l|l|l|l|l|l|}
\hline \multirow{2}{*}{ Relation } & $\begin{array}{l}\text { Direct } \\
\text { effect }\end{array}$ & $\begin{array}{l}\text { Direct } \\
\text { effect }\end{array}$ & $\begin{array}{l}\text { Indirect } \\
\text { effect }\end{array}$ & $\begin{array}{l}\text { Total } \\
\text { effect }\end{array}$ & $\begin{array}{l}\text { Total } \\
\text { effect }\end{array}$ \\
\cline { 2 - 6 } T value & Beta & Beta & T value & Beta \\
\hline $\begin{array}{l}\text { Collecting requirements } \\
\text { on User Involvement }\end{array}$ & 1.89 & 0.21 & & 1.89 & 0.21 \\
\hline $\begin{array}{l}\text { User Involvement in } \\
\text { Successful Project } \\
\text { Scope Management }\end{array}$ & 1.80 & 0.03 & & 1.80 & 0.03 \\
\hline $\begin{array}{l}\text { Collecting requirements } \\
\text { on Successful Project } \\
\text { Scope Management } \\
\text { mediating by User } \\
\text { Involvement }\end{array}$ & & 0.006 & & \\
\hline $\begin{array}{l}\text { Collecting requirements } \\
\text { on Successful Project } \\
\text { Scope Management }\end{array}$ & $\begin{array}{l}1.70 \\
\text { Partially } \\
\text { mediate }\end{array}$ & -0.07 & & 5.81 & -0.06 \\
\hline
\end{tabular}

Lastly, in the final section, the statistical results emphasise that the $T$ value test result underwent application through PLS to validate whether User Involvement plays a mediatory role in the link between Project Scope Management processes (Collecting requirements, Defining scope, Verifying scope, controlling scope) and Successful Project Scope Management (see tables 10-13).

In relation to the above table 10 , the $\mathrm{T}$ value identified between the Collecting requirements and User Involvement is recognised as having a value of 1.89. As such, it is seen to be significant at the 0.05 level. Further, the $T$ value between User Involvement and Successful Project Scope Management is determined as 1.80. Accordingly, it was found to be significant at the 0.05 level. In regards the Beta value for Indirect Effect, this is calculated as being 0.006, which highlights that change of one amount in collecting requirements and User Involvement induces a change amounting to 0.006 in Successful Project Scope Management. Such findings underpin the acceptance of H.4.1. As a result, User Involvement is applied in order to partially mediate Collecting requirements and Successful Project Scope Management in government IT departments in Jordan.

In relation to the above table 11 , the $\mathrm{T}$ value identified between Defining scope and User Involvement is recognised as having a value of 3.73. As such, it is seen to be significant at the 0.05 level. Further, the $\mathrm{T}$ value is determined as being 1.80 between User Involvement and Successful Project Scope Management. Accordingly, it was recognised as being significant at the 0.05 level. Further, the Beta value for Indirect Effect is calculated as 0.003, which further highlights that change in one amount in Defining scope and User Involvement will induce alteration amounting to 0.003 in Successful Project Scope Management. Such findings provide support for the acceptance of H.4.2. As such, User Involvement is recognised as being fully mediated between Defining scope and Successful Project Scope Management across the government IT departments in Jordan.

TABLE XI. TEST RESUlTS FOR DEFINING SCOPE AND SUSSECCFUL PROJECT SCOPE MANAGEMENT MEDIATING BY USER INVOLVEMENT

\begin{tabular}{|c|c|c|c|c|c|}
\hline \multirow{2}{*}{ Relation } & $\begin{array}{l}\text { Direct } \\
\text { effect }\end{array}$ & $\begin{array}{l}\text { Direct } \\
\text { effect }\end{array}$ & $\begin{array}{l}\text { Indirect } \\
\text { effect }\end{array}$ & $\begin{array}{l}\text { Total } \\
\text { effect }\end{array}$ & $\begin{array}{l}\text { Total } \\
\text { effect }\end{array}$ \\
\hline & $\mathrm{T}$ value & Beta & Beta & $\mathrm{T}$ value & Beta \\
\hline $\begin{array}{l}\text { Defining scope on User } \\
\text { Involvement }\end{array}$ & 3.73 & 0.13 & & 3.73 & 0.13 \\
\hline $\begin{array}{l}\text { User Involvement in } \\
\text { Successful Project Scope } \\
\text { Management }\end{array}$ & 1.80 & 0.03 & & 1.80 & 0.03 \\
\hline $\begin{array}{l}\text { Defining scope on } \\
\text { Successful Project Scope } \\
\text { Management mediating } \\
\text { by User Involvement }\end{array}$ & & & 0.003 & & \\
\hline $\begin{array}{l}\text { Defining scope on } \\
\text { Successful Project Scope } \\
\text { Management }\end{array}$ & $\begin{array}{l}0.16 \\
\text { Fully } \\
\text { mediate }\end{array}$ & 0.00 & & 0.59 & 0.003 \\
\hline
\end{tabular}

TABLE XII. TEST RESUlTS FOR VERIFYING SCOPE AND SUCCESSFUL PROJECT SCOPE MANAGEMENT MEDIATING BY USER INVOLVEMENT

\begin{tabular}{|l|l|l|l|l|l|}
\hline \multirow{2}{*}{ Relation } & $\begin{array}{l}\text { Direct } \\
\text { effect }\end{array}$ & $\begin{array}{l}\text { Direct } \\
\text { effect }\end{array}$ & $\begin{array}{l}\text { Indirect } \\
\text { effect }\end{array}$ & $\begin{array}{l}\text { Total } \\
\text { effect }\end{array}$ & $\begin{array}{l}\text { Total } \\
\text { effect }\end{array}$ \\
\cline { 2 - 6 } & T value & Beta & Beta & $\begin{array}{l}\text { T } \\
\text { value }\end{array}$ & Beta \\
\hline $\begin{array}{l}\text { Verifying scope of } \\
\text { User Involvement }\end{array}$ & 7.95 & 0.60 & & 7.95 & 0.60 \\
\hline $\begin{array}{l}\text { User Involvement in } \\
\text { Successful Project } \\
\text { Scope Management }\end{array}$ & 1.80 & 0.03 & & 1.80 & 0.03 \\
\hline $\begin{array}{l}\text { Verifying scope of } \\
\text { Successful Project } \\
\text { Scope Management } \\
\text { mediating by User } \\
\text { Involvement }\end{array}$ & & 0.018 & & \\
\hline $\begin{array}{l}\text { Verifying scope of } \\
\text { Successful Project } \\
\text { Scope Management }\end{array}$ & $\begin{array}{l}2.49 \\
\text { partially } \\
\text { mediate }\end{array}$ & 0.09 & & 2.79 & 0.108 \\
\hline
\end{tabular}


In relation to the above table 12 , the $\mathrm{T}$ value is identified as 7.95 between the Verifying scope and User Involvement. Accordingly, the value was seen to be significant at the 0.05 level. In addition, the $\mathrm{T}$ value between User Involvement and Successful Project Scope Management is calculated as being 1.80. As such, it was viewed as being significant at the 0.05 level. Further, the Beta value for Indirect Effect is highlighted as 0.018, which explains that change in one amount in Verifying scope and User Involvement will subsequently induce change amounting to 0.018 in Successful Project Scope Management. Such findings provide support for H.4.3. As a result, User Involvement is recognised as providing partially mediation between Verifying scope and Successful Project Scope Management across government IT departments in the Jordanian context.

TABLE XIII. TEST RESUlTS FOR CONTROLLING SCOPE AND SUCCESSFUL PROJECT SCOPE MANAGEMENT MEDIATING BY USER INVOLVEMENT

\begin{tabular}{|l|l|l|l|l|l|}
\hline \multirow{2}{*}{ Relation } & $\begin{array}{l}\text { Direct } \\
\text { effect }\end{array}$ & $\begin{array}{l}\text { Direct } \\
\text { effect }\end{array}$ & $\begin{array}{l}\text { Indirect } \\
\text { effect }\end{array}$ & $\begin{array}{l}\text { Total } \\
\text { effect }\end{array}$ & $\begin{array}{l}\text { Total } \\
\text { effect }\end{array}$ \\
\cline { 2 - 6 } T value & Beta & Beta & $\begin{array}{l}\text { T } \\
\text { value }\end{array}$ & Beta \\
\hline $\begin{array}{l}\text { Controlling scope of } \\
\text { User Involvement }\end{array}$ & 4.54 & 0.14 & & 4.54 & 0.14 \\
\hline $\begin{array}{l}\text { User Involvement in } \\
\text { Successful Project } \\
\text { Scope Management }\end{array}$ & 1.80 & 0.03 & & 1.80 & 0.03 \\
\hline $\begin{array}{l}\text { Controlling scope of } \\
\text { Successful Project } \\
\text { Scope Management } \\
\text { mediating by User } \\
\text { Involvement }\end{array}$ & & & & & \\
\hline $\begin{array}{l}\text { Controlling scope of } \\
\text { Successful Project } \\
\text { Scope Management }\end{array}$ & $\begin{array}{l}124.17 \\
\text { partially } \\
\text { mediate }\end{array}$ & 0.96 & & 5.81 & 0.964 \\
\hline
\end{tabular}

In relation to table 13 , the $\mathrm{T}$ value between Controlling scope and User Involvement is identified as being 4.54. As such, it is considered to be significant at the 0.05 level. Furthermore, the $\mathrm{T}$ value between User Involvement and Successful Project Scope Management is established as being 1.80. Accordingly, it was seen to be significant at the 0.05 level. Further, the Beta value for Indirect Effect is calculated as 0.004 , which further highlights that change of one amount in Controlling scope and User Involvement will induce change amounting to 0.004 in Successful Project Scope Management. Such findings provide support for the acceptance of H.4.4. As a result, User Involvement is recognised as presenting partially mediation between Controlling scope and Successful Project Scope Management across governmental IT departments in the Jordanian context.

\section{CONCLUSION}

Very little is known in the field of Project Scope Management processes and User Involvement, meaning it would be difficult to postulate as to the very best practice in this arena. This paper, however, provides outcomes that present reliable instruments for key factors in the analysis of Project Scope Management processes and User Involvement, with a number of valuable recommendations able to made in line with Successful Project Scope Management. In this work, a number of different factors were highlighted as requiring examination in consideration to their influence on Successful
Project Scope Management within IT departments across governmental institutions in the Jordanian context. This work further centred on achieving empirically findings in regards the relative strength of causal relations on User Involvement, which fully mediates the link between defining scope and Successful Project Scope Management across governmental IT departments in the Jordanian context. Moreover, the findings provide insight into the relative strength of causal links on User Involvement, which suggest a partially mediation in regards the link between Collecting requirements, Verifying scope, and Controlling scope, and Successful Project Scope Management across IT departments in governmental institutions in the Jordanian context. It is stated in conclusion that Project Scope Management tools and techniques could undergo adaptation in IT departments in governmental institutions, with the value of such between demonstrated in the creative arena in Jordan.

\section{REFERENCES}

[1] Falk, R.F., and Miller, N.B. (1992) A Primer for Soft Modeling. Akron, $\mathrm{OH}$ : The University of Akron Press.

[2] Morris, P. W. G. (2010). Research and the future of project management. International Journal of Managing Projects in Business, 3(1), 139-146.

[3] Too,G.T., and Weaver ,P (2014) The management of project management: A conceptual framework for project governance, International Journal of Project Management, 32(8), pp. 1382-1394.

[4] Osorio,P.C., Quelhas,O.L., Zotes,L.P., Shimoda,E., \& França,S (2014) Critical Success Factors in Project Management: An Exploratory Study of an Energy Company in Brazil, Global Journal of Management and Business Research: A Administration and Management, 14(10), pp. 3850.

[5] Fageha,M.K., and Aibinu,A.A(2013). Managing Project Scope Definition to Improve Stakeholders' Participation and Enhance Project Outcome, Procedia - Social and Behavioral Sciences 74 ( 2013 ) 154-164.

[6] Ajelabi,I and Tang,Y(2010) The Adoption of Benchmarking Principles for Project Management Performance Improvement, International Journal of Managing Public Sector Information and Communication Technologies (IJMPICT). 1( 2),pp.1-8.

[7] Mian Ajmal,M., Helo,P., and Kekale,T(2010) Critical factors for knowledge management in project business, Journal of Knowledge management, 14(1) pp. 156-168.

[8] Kwak,Y.H., and Anbari,F.T (2009) Analyzing project management research: Perspectives from top management journals, International Journal of Project Management 27, 435-446.

[9] Hornstein, H.A (2015) The integration of project management and organizational change management is now a necessity, International Journal of Project Management 33, 291-298.

[10] Travaglini ,A., Radujkovic M., Mancini ,M., (2014) building information modeling (bim) and project management a stakeholder perspective, organization, technology and management in construction . an international journal, 6(2), PP. 1058-106.

[11] Talet, A.N., Karadsheh,L., AL Jarrah,M.A., and Alhawari S (2018) Risk monitoring through better knowledge-based risk processes, Journal of Operational Risk 13(3), pp.1-25.

[12] Alnsour, B.H(2014) The use of virtual project teams for project management in Jordanian corporation, Eurasian Journal of Business and Management, 2(2),50-60.

[13] Alhawari S., Karadsheh L., Talet, A. Nehari Talet., and Mansour,E.,(2012) Knowledge-Based Risk Management Framework for Information Technology Project, International Journal of Information Management,32(1), pp. 50-65.

[14] Alkhaffaf ,M., AL Jarrah,M.A., Karadsheh L., and Alhawari S (2018) Factors affecting ERP implementation success in Jordanian commercial banks sector, International Journal Economics and Business Research,15(4), pp.417-441. 
[15] Al Freidi,S.S (2014) Determinants of the Best Practices for Successful Project Management, International Journal of u- and e- Service, Science and Technology 7(3), pp.173-186.

[16] Mirza,M.N., Pourzolfaghar,Z., and Shahnazari,Z (2013) Significance of Scope in Project Success, Procedia Technology, 9, pp.722-729.

[17] Olsson,N.O (2015). Implementation of pre-defined potential scope reductions in projects, Procedia Computer Science 64, 387-394.

[18] Alhawari S.(2016). Relationship among Project Management Processes and Knowledge Repository for Project Success, International Journal of Enterprise Information Systems (IJEIS), Vol.12 No.4 pp.16-30.

[19] Nikumbh,A.R., and Pimplikar, S.S (2014) Role of Project Management Consultancy in Construction Project, IOSR Journal of Mechanical and Civil Engineering, 10,(6)pp. 14-19.

[20] PMI. (2013) A Guide to the Project Management Body of Knowledge: PMBOK Guide, 5th ed., PMI - Project Management Institute, Pennsylvania, USA.

[21] Sánchez, M.A ., \& Schneider,D.E(2014) Project management, strategic management and Sustainable development: a review of the literature, Revista Metropolitana de Sustentabilidade, 4(3), pp. 28-49.

[22] Marinho, M , Sampaio, S Lima, T., and Moura, H.D(2014) A Guide to deal with uncertainty in software Project management, International Journal of Computer Science \& Information Technology (IJCSIT) 6,(5), pp. 1-20.

[23] Seresht,M.Z., Akbarijokar, M., Khosravi,S., Afshari,H(2014) Construction Project Success ranking through the Data Envelopment Analysis, Journal of Data Envelopment Analysis and Decision Science, 3(1) pp. 1-13.

[24] Nenni, M.E., Arnone,V., Boccardelli,P., and Iolanda,N(2014) How to Increase the Value of the Project Management Maturity Model as a
Business-oriented Framework, International Journal of Engineering Business Management, 6, pp. 1-7.

[25] Mir,F.A and Pinnington,A.H (2014) Exploring the value of project management: Linking Project Management Performance and Project Success, International Journal of Project Management 32, pp. 202-217.

[26] Purna ,S, G. (2012). A model of critical success factors for software projects. Journal of Enterprise Information Management, 25(6), 537-558.

[27] Silvius, A. J. and Schipper, R P. (2014) Sustainability in Project Management Competencies: Analyzing the Competence Gap of Project Managers, Journal of Human Resource and Sustainability Studies, 2, pp. 40-58.

[28] Project Management Institute, I. (2004). A guide to the project management body of knowledge: PMBOK guide (3rd ed.). Project Management Institute. (p. 380).

[29] Saundres, M., Lweis, P., and Thornhil, A. (2009) 'Research Methods for Business Student', (6th ed), prentice hall.

[30] Hair, J.F. Black, B. Babin, B. Anderson, R.E., and Tatham, R.L. (2006) Multivariate Data Analysis, (6th ed), New Jersey: Pearson Prentice Hall.

[31] Fornell, C., and Larcker, D.F. (1981) Evaluating Structural Equations Models with Unobservable Variables and Measurement Error, Journal of Marketing Research, 18(1), pp. 39-50.

[32] Anderson. J., and Gerbing, D. (1988), "Structural equation modeling in practice: A review and recommended two-step approach," Psychological Bulletin, 103(3), 411-423.

[33] Nunnally, J.C. and Bernstein, I.H. (1994). Psychometric Theory. New York, McGraw-Hill.

[34] Gaur, A.S. and Gaur, S.S. (2006) Statistical Methods for Practice and Research: A Guide to Data Analysis using SPSS, (1st ed), Thousand Oaks, California: Sage. 